\title{
Effects of the Chinese Innovation System on Regional Innovation Performance
}

\author{
Kou Kou* \\ Center for Economics of Materials (CEM) and Department of Economics, Martin-Luther-University Halle-Wittenberg, \\ Halle, Germany \\ Email: kou.kou@wiwi.uni-halle.de
}

How to cite this paper: Kou, K. (2018) Effects of the Chinese Innovation System on Regional Innovation Performance. Technology and Investment, 9, 36-51. https://doi.org/10.4236/ti.2018.91003

Received: December 22, 2017

Accepted: February 24, 2018

Published: February 27, 2018

Copyright $\odot 2018$ by author and Scientific Research Publishing Inc. This work is licensed under the Creative Commons Attribution International License (CC BY 4.0).

http://creativecommons.org/licenses/by/4.0/

\begin{abstract}
This paper presents the influence of innovation systems on regional innovation performance in China for the period 1998-2008. It places special emphasis on the effects of institutional factors, namely marketization level. The findings indicate that the innovation system contributes greatly to increasing the level of innovation. Among the factors of innovation systems, the openness of the region and government expenditure on education plays key roles. Market-oriented institutional arrangements also increase innovation performance.
\end{abstract}

\section{Keywords}

Innovation Performance, Innovation Systems, Marketization Reform

\section{Introduction}

China's transformation from a centrally planned system to a market-oriented economy has been a great success: Since the beginning of the "Reform and opening up policy" in 1978, China's gross domestic product (GDP) has increased by approximately $9.8 \%$ per year. With the economic boom, China's level of innovation has also been increasing rapidly, and consequently, innovation performance has already become a crucial factor for national competitiveness.

Currently, researches are paying more attention to the innovation system in innovation research. According to a report by the Organization for Economic Cooperation and Development (OECD), innovation is the result of a complex interaction between various actors and institutions. Technical change does not occur in a perfectly linear sequence, but through feedback loops within this system. The innovation system includes a network of enterprises, universities, research institutes and governments, where the flows of technology, information ${ }^{\star}$ Chair of economic policy research. 
and knowledge among people are key to the innovative process [1].

Research on innovation systems was initially carried out at the national level. Patel and Pavitt [2] have built a framework for the analysis of national innovation systems and believed that it should consider immaterial investment in technological learning. This refers to the whole institution (essentially enterprises, universities and governments), the linkage between them and their infrastructure. In empirical studies, Furman, Porter, and Stern [3] investigate the innovative capacity in OECD countries, and $\mathrm{Hu}$ and Mathews [4] [5] examine the same for the four East Asian "Tiger" economies (Hong Kong, Singapore, South Korea and Taiwan) as well as Mainland China, with the help of Furman, Porter and Stern's model (FP \& S). Longitudinal comparisons at the national level, however, often fall into dispute. Rosenberg and Nelson [6] point out that regions and industries within one country can be different. The national innovation system cannot reflect the performance of individual actors well. Asheim and Isaksen [7] demonstrate that regional (subnational) resources and innovation activities are essential for companies to increase their global competitiveness.

In emerging countries like China, regional diversity is greater than in industrialized ones; thus, research at the national level may reflect real situations inaccurately. Moreover, many articles ignore institutional transformation factors such as marketization, which is seen as one of the most important reasons for technical progress in China [8]. Thus, in this paper, we investigate regional innovation performance in China at the provincial level and analyze the effects of innovation systems at the level of innovation output. We use a methodology introduced by Furman, Porter, and Stern [3], who present an examination of the determinants of patent production in 17 OECD countries. We use the number of patents granted per Chinese province between 1998 and 2008 as an indicator for regional innovative output.

Although Furman, Porter, and Stern [3] introduce their model at the national level, we believe that it is still suitable for regional innovation, as Chinese provinces can be regarded as countries in terms of geographic characteristics and freedom and independence in the area of economic policy [9]. The innovation system in this paper is divided into three parts: institution and policy, namely innovation infrastructure; location and actors in clusters (cluster milieu); and the linkage between them. In innovation infrastructure, the marketization level is included, because market power could not be limited if the market lacks market entry freedom and competition [10]. Our results demonstrate that the regional innovation system, particularly its innovation infrastructure, affects innovation performance.

This paper is organized as follows: Section 2 presents the theoretical basis and econometric model; Sections 3 and 4 demonstrate the dataset and research results and Section 5 is the conclusion.

\section{Theoretical Basis and Model}

This paper is based on the FP \& S model [3]. The framework of the model is 
based on three different theories: ideas-driven endogenous growth theory [11], the theory of national industrial competitive advantage [12] and national innovation systems [13]. Romer's growth theory focuses on innovation input, that is to say, new input and knowledge stock, while the latter two theories focus on innovation systems.

According to the knowledge production function, knowledge production is a function of new input into research and development (R \& D) and the stock of knowledge. Technological progress and the accumulation of knowledge are both the consequence of economic development and forces that promote economic development at the same time. The knowledge production function can be formulated as follows:

$$
\dot{A}_{t}=\delta L_{A, t}^{\lambda} A_{t}^{\phi}
$$

where $\dot{A}_{t}$ stands for the output of the new knowledge and innovation in year $t$, $L_{A, t}^{\lambda}$ for human capital which is invested in $\mathrm{R} \& \mathrm{D}$ and $A_{t}^{\phi}$ for knowledge accumulation in year $t$.

Because the growth of knowledge stock depends on $\mathrm{R} \& \mathrm{D}$ professionals, the influence of the state should not be ignored. Good governance is a "good" process of decision-making and the process by which decisions are implemented (or not implemented) [14]. It includes participation, rule of law, transparency and a market-oriented economy. Government policy, which is relevant to the professional workforce and R \& D activities in the long term, contributes to economic growth.

Porter develops the theory of national competitive strategy, namely the diamond model, which evaluates the competitiveness of industries and companies in a national cluster. In a domestic cluster, there are four important factors: 1) factor conditions including product factors such as human capital, real capital and knowledge resources, 2) competition promoting the innovation and productivity of enterprises; however, stress does not only come from local competitors, but also from international rivals, which depends on the level of openness, 3) demand conditions influencing innovation behavior, when sophisticated domestic clients pressure firms to be more efficient and create more advanced products and 4) related and supporting industries providing the fundamental infrastructure, which strengthens the knowledge spill-over effect through communication among geographically nearby industries and reduces transaction costs. Two additional factors should not be discounted: one is chance, which affects competition but is beyond the control of a firm. The other is government, which can influence each of the four determinants above (either positively or negatively). Traditional innovation policy focuses mainly on correcting market failure and maintaining competition orders through competition policy, while the innovation system theory emphasizes the interaction synthesis effect between different actors. Innovation-oriented competition in domestic clusters determines the innovation performance of firms and industries [12]. The firms play a key role in the competition and innovation process. The government needs to provide necessary resources and a fair growth milieu for firms. 
Similar to Porter, Nelson attaches great value to the impact of institutions and systems [13]. His national innovation system highlights the importance of state policy and specific institutions for innovation. Furman, Porter and Stern combine all the three of the theories above and divide the determinants of the national innovation environment into three categories: 1) infrastructure, innovation resources and policy, 2) the role of the industrial cluster and 3) the linkage between these two parts [3]. The new national innovative capacity framework suggests not only the general innovation input formulated in the Romer function (1) but also the determinants of the innovative milieu:

$$
\dot{A}_{j, t}=\delta_{j, t}\left(X_{j, t}^{I N F}, Y_{j, t}^{C L U S}, Z_{j, t}^{L I N K}\right) L_{j, t}^{A \lambda} A_{j, t}^{\phi}
$$

where $\dot{A}_{j, t}$ denotes the innovation production of region $j$ in year $t, L_{j, t}^{A \lambda}$ the input of capital and human resources and $A_{j, t}^{\phi}$ the knowledge stock. The vector $X_{j, t}^{I N F}$ is the entire innovation infrastructure, the $\mathrm{R} \& \mathrm{D}$ activities of the government and the openness of the region; vector $Y_{j, t}^{C L U S}$ is the cluster-specific circumstance for innovation in the region, particularly universities and research institutes and $Z_{j, t}^{L I N K}$ is the linkage between the innovation infrastructure and the cluster.

Vectors $X_{j, t}^{I N F}, Y_{j, t}^{\text {CLUS }}$ and $Z_{j, t}^{L I N K}$ complement each other and play a role similar to indicators of innovation input and knowledge accumulation. These three factors are introduced in exponential form; thus, Equation (2) would be rewritten into a new form, $\dot{A}_{j, t}=\delta X_{j, t}^{I N F \delta_{1}} Y_{j, t}^{C L U S \delta_{2}} Z_{j, t}^{L I N \delta_{3}} L_{j, t}^{A \lambda} A_{j, t}^{\phi} \quad$ [15], which can be transformed into a new model via a logarithmic transformation (the natural logarithm of " $I n$ " in model (3)):

$$
\ln \dot{A}_{j, t}=\delta_{1} \ln X_{j, t}^{I N F}+\delta_{2} \ln Y_{j, t}^{C L U S}+\delta_{3} \ln Z_{j, t}^{L I N K}+\lambda \ln L_{j, t}^{A}+\phi \ln A_{j, t}+\epsilon_{j, t}
$$

Furman, Porter and Stern [3] and Hu and Mathews [4] [5] apply model (3) to the national level for the OECD and Asian countries, yet the model could also be appropriate for the regional innovation systems on a provincial level in China for the following reasons: 1) with regard to area, population and economic volume, most Chinese provinces are as large as a country. 2) Since the reform of the late 1970s, and especially since the 1990s, the central government has given more and more freedom in terms of economic policy to local governments, who can now decide most concrete economic measures by themselves. 3) It is reasonable to analyze at a local instead of a national level, because the development stages, culture and habits are quite different in different provinces of China [16].

Regional decentralization has shaped China's transition. In China's institutions, which are viewed as a regionally decentralized authoritarian system, the central government has control over personnel affairs, while local governments are responsible for the economy [17]. Li [18] estimates the determinants for the disparity between the innovative capacities of China's provinces by analyzing the innovation subjects in innovation systems. He divides the innovation system into two parts. The first part concerns the participants in a region, including companies, universities, research institutes, the government and the interaction be- 
tween these participants. The other part is institutions such as rules and the relationship between government and market. But this kind of institution is normally established at a national level, while the impact of regional institutional factors is frequently ignored. The changes of innovation participants and the differences in the innovative capacity of companies at a regional level has led to the gap in regional innovative capacity. However, reform and the division of power have induced local institutional competition in China [9] [19], which has resulted in regional institutional divergence. As such, Hypothesis 1 is that the innovation system influences regional innovation performance in China.

Unlike the OECD countries, China is a latecomer and has experienced massive reforms and a process of transformation to a market-oriented economy in the last decades. Marketization refers to building an order of fair competition and an economic system where the market plays a fundamental role in resource allocation. Park, Li and David [20] find that the market-oriented reform, including the decentralization of control, refreshing the government-firm relationship, improving the competitive environment and defining property rights clearly, has affected the economic performance of China by shaping incentives in management and changing transaction and agency costs.

Thanks to the Chinese marketization index of the Chinese National Economic Research Institute [8], we can quantify and distinguish the important institutional factors in terms of marketization. We apply the marketization index to the innovation infrastructure parameters $X_{j, t}^{I N F}$. Hypothesis 2 is formulated as follows: market-oriented institutions have a positive impact on China's regional innovation performance.

In the following sections, we evaluate the extent to which the regional innovation system influences China's local innovation performance, thereby analysing the innovation infrastructure, cluster milieu and linkages between them with the help of the model of Furman, Porter and Stern [3]. We place special emphasis on the impact of the marketization level.

\section{Data}

We established a panel dataset with information on the innovation activities of 30 Chinese provinces, autonomous regions and directly controlled municipalities in mainland China (hereinafter called provinces) between 1998 and $2008^{1}$, which is partly comparable to that employed by Furman, Porter and Stern [3] for the OECD countries. The data used here comes from the National Bureau of Statistics of China, the China Statistical Yearbook on Science and Technology from 1999 to 2009 and the National Economic Research Institute (NERI) Index of Marketization.

\subsection{Innovation Output}

We chose the number of patents granted as an indicator of regional innovation output. Patents are a frequently used variable for innovative activity in the lite-

${ }^{1}$ Due to missing values we exclude the data of Tibet. 
rature on innovation research, and the association between these two factors is widely recognized [2] [21] [22] [23] [24] [25]. Acs and Audretsch [26] and Acs, Anselin and Varga [27] argue that patents provide a fairly reliable measure of innovative capacity. Because patent laws and regulations have no large differences at the provincial level in China, patents are an appropriate indicator for reflection regional levels of innovation. In this paper, we only used the invention patent, because compared with the other two types (utility and design patents), invention patents require more high-tech and are often used as an indicator for independent intellectual property [28].

Generally, the process from patent application to granting lasts a period of time, so we had to consider the lag between research input and patent output. Furman and Hayes [15], Furman, Porter and Stern [3] and Hu and Mathews [4] [5] use a lagged variable of three years in their regression. In China, this process usually lasts three years as well [29]. As such, we imported the number of domestic invention patents granted in year $t+3$ (PATENT_GRA) and patents granted per capita in year $t+3$ (in terms of population, in millions) (PATENT_POP).

Figure 1 and Figure 2 report two province-level measures of differences in

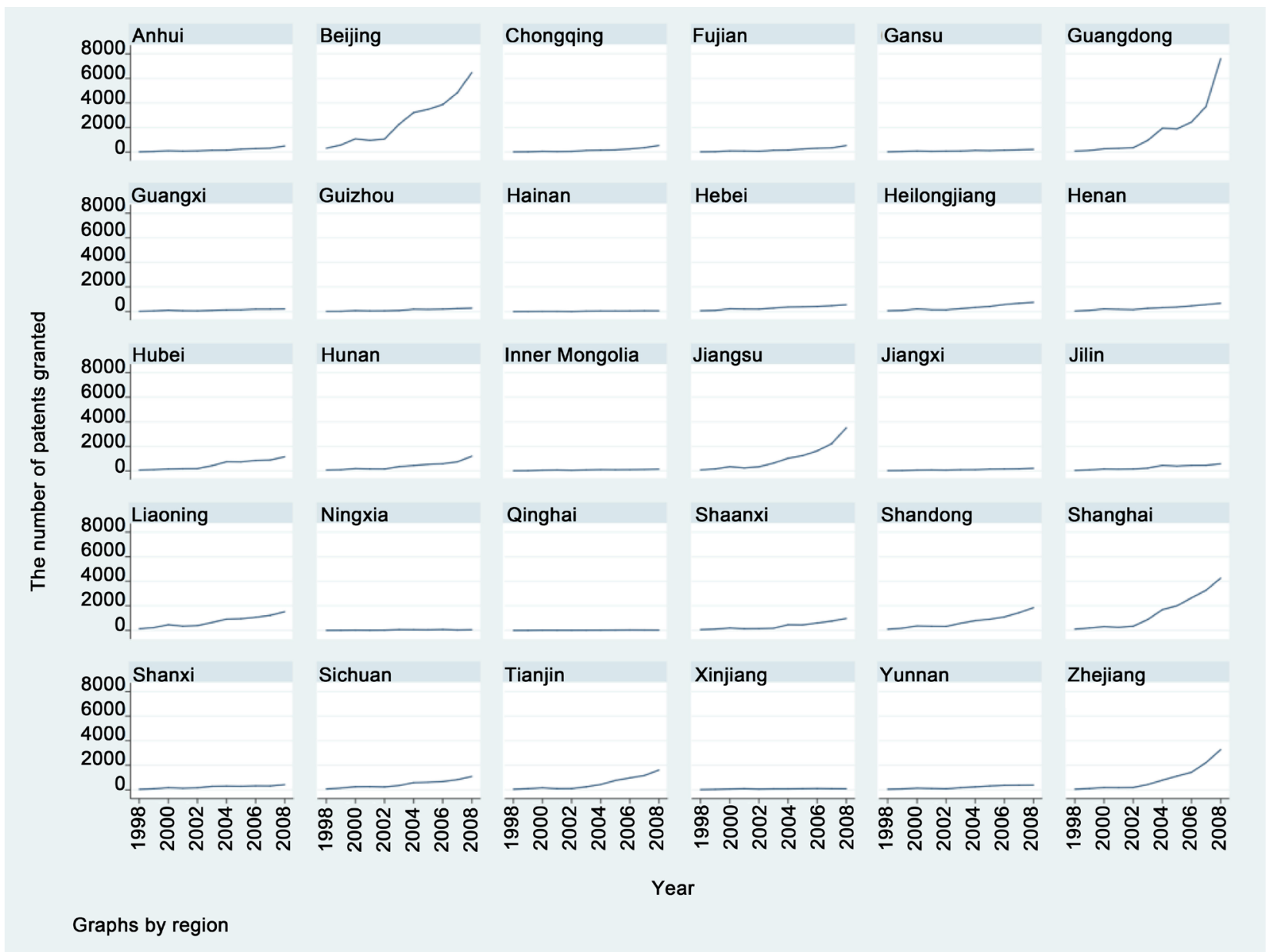

Source: National Bureau of Statistics of China.

Figure 1. The number of patents granted of Chinese provinces from 1998 to 2008. 


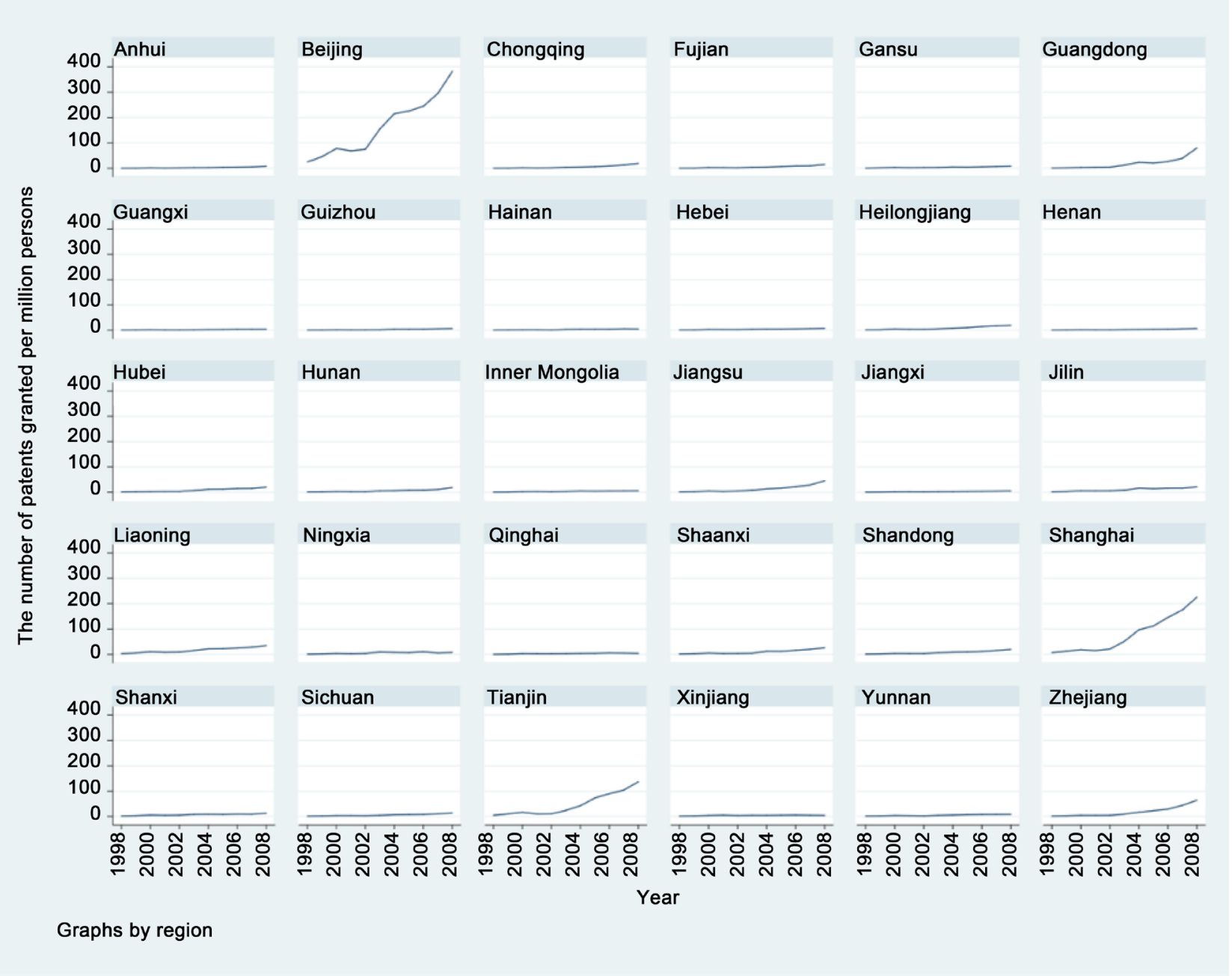

Source: National Bureau of Statistics of China.

Figure 2. The number of patents granted per million persons of Chinese provinces from 1998 to 2008.

the intensity of innovation across regions. Figure 1 presents the total number of patents granted, and Figure 2 provides the number per million residents between 1998 and 2008. Both of the graphs demonstrate that there are distinct trends in innovation performance among provinces. Beijing and Shanghai are the most innovative regions in China. Guangdong, Jiangsu, Zhejiang and Tianjin also could be seen as important innovation centres, while the other regions suffer from a relatively low level of innovation performance. This phenomenon also demonstrates the necessity of controlling for the individual effects of provinces in regressions.

\subsection{Traditional Innovation Input and Knowledge Accumulation}

According to the FP \& S model, innovation input includes professional labor forces (or real capital) and knowledge stock. For labor input, we used the number of full-time equivalents of $\mathrm{R} \& \mathrm{D}$ personnel in a province from the China Statistical Yearbook on Science and Technology from 1999 to 2009 (PERSONAL), 
which contains all of the full-time R \& D staff in research institutes, universities and enterprises. For knowledge stock, we employed the GDP per capita of the province. Per capita GDP captures the ability of a country, or in this case a province, to translate its knowledge stock into a realized state of economic development (and thus yields an aggregate control for a country's, or province's, technological sophistication) [3]. Figure 3 demonstrates the number of R \& D employees in each province between 1998 and 2008. Beijing, Guangzhou, Jiangsu and Zhejiang have invested more in R \& D employees than the other provinces, which corresponds partly to the innovation output presented in Figure 1 and Figure 2.

\subsection{Indicators of Innovation Systems}

Innovation infrastructure refers to factors of fundamental institutions and the role of the government. We imported the percentage of international trade volume in relation to GDP (OPENNESS) and the share of education expenditure of total government spending (ED_SHARE). Another important element is the

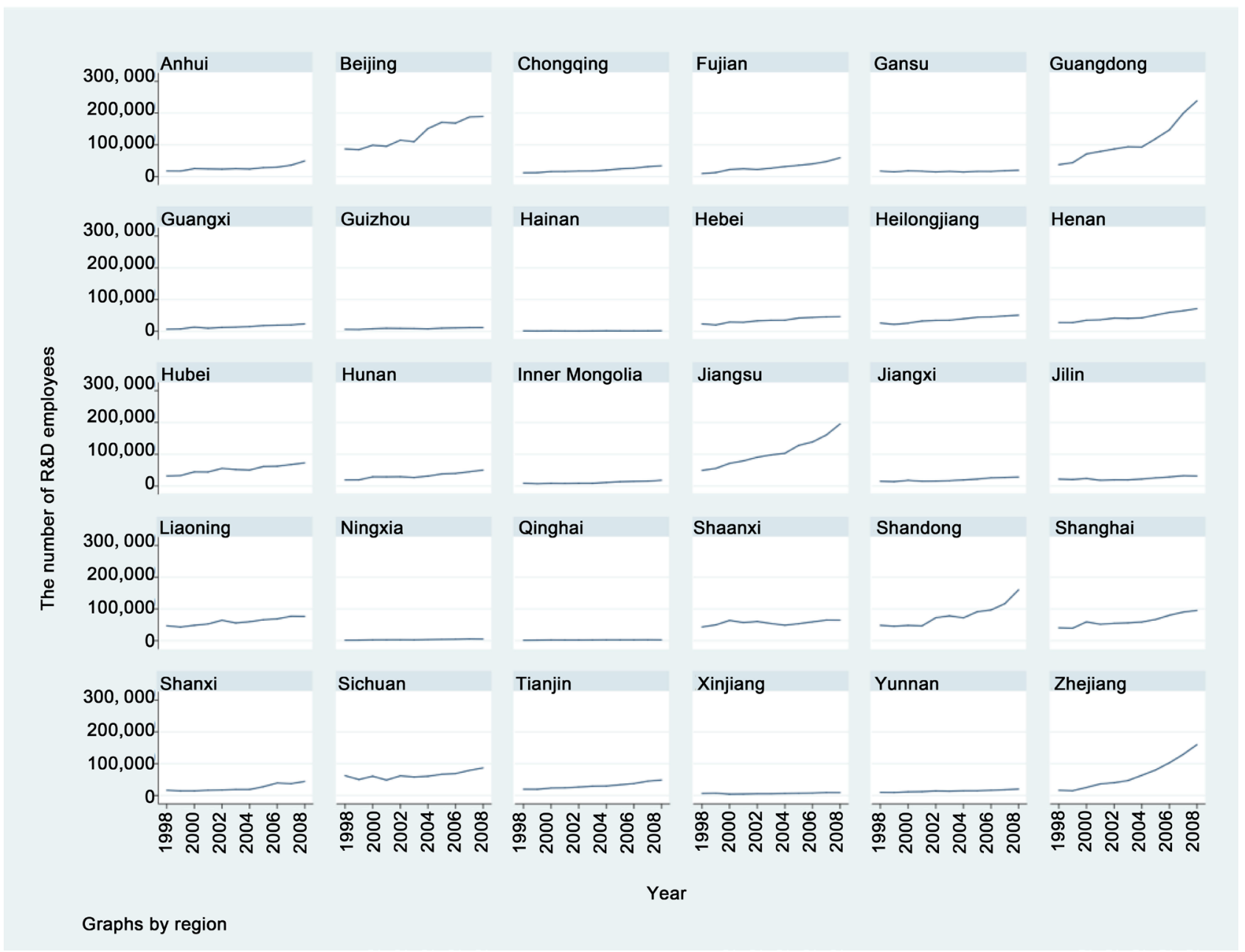

Source: National Bureau of Statistics of China.

Figure 3. R \& D human capital. 
marketization process. The experience of industrial countries has proven that the best way to modernize is to build a market-based economic system [30]. The NERI Marketization Index measures the marketization levels of 31 provinces of Mainland China between 1997 and 2009 and demonstrates the growth process of a market-oriented economy in China. This index has been widely used by many researchers to measure regional institutional development [31] [32] [33] [34] [35]. The higher the point value is, the more "market-oriented" the province is. Marketization is divided into five subcategories: 1) the relationship between government and market, such as the role of markets in allocating resources; 2) the development of non-state economy, such as industrial output of private sector; 3) the development of product markets, such as regional trade barriers; 4) the development of factor markets, such as foreign direct investment and mobility of labor; and 5) the development of intermediary organizations and the legal system, such as the protection of property rights [32]. We introduce the development of intermediary organizations and the legal system (rule of law) (INTER) which encompasses the development of intermediary organizations, the protection of the rights of employees, intellectual property and the protection of the rights of consumers. In China, legislative power is exercised by the National People's Congress at the national level. The province has no power to adopt laws, but it may enact corresponding local orders and regulations and must create a fair environment for the rule of law. In order to estimate the effects of marketization reform more precisely, we added another subcategory to this index, which contains concrete indicators of market-oriented institutions: the protection of intellectual property (IP).

Besides infrastructure, regional innovation performance also depends on the milieu of concrete clusters at a meso-level. The variable that we chose as indicator of the properties of clusters and industry structure is the share of the tertiary sector of GDP. As Porter [12] argues, individual clusters tend to be associated with the industrial structure of local areas. We introduced the share of the tertiary sector of a province's GDP (TERTIARY) as a proxy for economic structure in a province's cluster.

For a given cluster innovation environment, innovation output may tend to increase with the strength of the common innovation infrastructure [3]. Network formation and establishing new linkages might be established by affecting career patterns and incentive systems in firms and at universities [36]. The connection and interaction between infrastructure and innovation-oriented clusters, as well as between R \& D and production in clusters, are essential for an innovation system. This relationship can be interpreted through the behavior of institutions, such as research institutes, universities and financial institutions that fill in the blanks in the network. As such, we introduced two variables of this linkage. The first is the share of universities' $\mathrm{R} \& \mathrm{D}$ spending of the total $\mathrm{R} \& \mathrm{D}$ expenditure (UNI_RD). In latecomer countries, several fields of academic science are application-oriented, because these countries require more practical engineers 
for construction. This model not only influences people in industry, but also develops the scientific foundations of industrial technologies [4]. The second variable is the contribution of bank credit to $S \& \mathrm{~T}$ activities in a province (BANK). The bank plays a crucial role in China's economic growth and did so particularly when China was still lacking wide-ranging financing channels decades ago. As such, we calculated the share of bank credits in total S \& T funding to estimate the effect of financing channels. Table 1 presents the variable definitions and Table 2 the descriptive statistics for all variables.

\section{Empirical Results}

Table 3 reports the empirical results of our research. The dependent variable is

Table 1. Definition of variables.

\begin{tabular}{|c|c|c|c|}
\hline & Variable & Definitions & Source \\
\hline & L_PATENT_GRA & Log of granted patents in the province $i$ in year $(t+3)$ & National Bureau of Statistics of China \\
\hline$A_{j, t}^{\phi}$ & L_GDP_PC & Log of GDP per capita & National Bureau of Statistics of China \\
\hline$L_{j, t}^{A \lambda}$ & L_PERSONAL & Log of amount of full-time equivalent of R \& D personnel & China Statistical Yearbook on Science and Technology \\
\hline$X_{j, t}^{I N F}$ & OPENNESS & Openness level: trade volume/GDP & China Statistical Yearbook \\
\hline$X_{j, t}^{I N F}$ & ED_SHARE & Share of local government's expenditures spent on education & National Bureau of Statistics of China \\
\hline$X_{j, t}^{I N F}$ & INTER & Intermediary and law system & National Economic Research Institute \\
\hline$X_{j, t}^{I N F}$ & IP & Strength of protection for intellectual property & National Economic Research Institute \\
\hline$Y_{j, t}^{C L U S}$ & TERTIARY & Share of tertiary sector in GDP & National Bureau of Statistics of China \\
\hline$Z_{j, t}^{L I N K}$ & UNI_RD & Percentage of R \& D expenditures from universities & China Statistical Yearbook on Science and Technology \\
\hline$Z_{j, t}^{L I N K}$ & BANK & Contributions of bank to scientific and technical activities & China Statistical Yearbook on Science and Technology \\
\hline
\end{tabular}

Table 2. Descriptive statistics.

\begin{tabular}{cccccc}
\hline Variable & N & Mean & Std. Dev. & Min & Max \\
\hline L_PATENT_GRA & 240 & 5.579 & 1.313 & 1.792 & 8.936 \\
L_PATENT_POP & 240 & 2.064 & 1.158 & 0.100 & 5.946 \\
L_GDP_PC & 240 & 9.093 & 0.590 & 7.768 & 10.813 \\
L_PERSONAL & 240 & 9.942 & 1.117 & 6.743 & 12.050 \\
OPENNESS & 240 & 29.287 & 38.272 & 3.213 & 165.227 \\
ED_SHARE & 240 & 15.380 & 2.281 & 9.697 & 21.140 \\
INTER & 240 & 3.868 & 2.069 & 1.150 & 12.840 \\
IP & 240 & 2.621 & 3.835 & 0.010 & 25.130 \\
TERTIARY & 240 & 40.540 & 6.359 & 30.048 & 69.651 \\
UNI_RD & 240 & 10.039 & 5.828 & 0.958 & 30.943 \\
BANK & 240 & 6.920 & 4.773 & 0.000 & 27.210 \\
\hline
\end{tabular}


Table 3. Estimation results (granted patents as dependent variable).

\begin{tabular}{|c|c|c|c|c|}
\hline & (1) & (2) & (3) & (4) \\
\hline \multirow[t]{2}{*}{ L_GDP_PC } & $1.438^{\star \star \star}$ & $1.358^{\star * *}$ & $1.121^{\star * *}$ & $1.254^{\star * *}$ \\
\hline & $(0.186)$ & $(0.176)$ & $(0.193)$ & $(0.185)$ \\
\hline \multirow[t]{2}{*}{ L_PERSONAL } & $0.874^{* * *}$ & $0.651^{* * *}$ & $0.358^{\star * *}$ & $0.393^{* * *}$ \\
\hline & $(0.169)$ & $(0.149)$ & $(0.124)$ & $(0.130)$ \\
\hline \multirow[t]{2}{*}{ OPENNESS } & & $0.016^{* * *}$ & $0.012^{\star * *}$ & $0.009^{* *}$ \\
\hline & & $(0.003)$ & $(0.003)$ & $(0.004)$ \\
\hline \multirow[t]{2}{*}{ ED_SHARE } & & $0.090^{* * *}$ & $0.062^{* *}$ & $0.061^{* *}$ \\
\hline & & $(0.023)$ & $(0.023)$ & $(0.022)$ \\
\hline \multirow[t]{2}{*}{ INTER } & & & $0.087^{* * *}$ & \\
\hline & & & $(0.020)$ & \\
\hline \multirow[t]{2}{*}{ IP } & & & & $0.044^{* * *}$ \\
\hline & & & & $(0.014)$ \\
\hline \multirow[t]{2}{*}{ TERTIARY } & & & $0.071^{\star * \star}$ & $0.070^{\star \star \star}$ \\
\hline & & & $(0.010)$ & $(0.011)$ \\
\hline \multirow[t]{2}{*}{ UNI_RD } & & & 0.004 & 0.002 \\
\hline & & & $(0.007)$ & $(0.007)$ \\
\hline \multirow[t]{2}{*}{ BANK } & & & $-0.013^{*}$ & $-0.014^{\star}$ \\
\hline & & & $(0.007)$ & $(0.007)$ \\
\hline \multirow[t]{2}{*}{ _cons } & $-16.180^{\star * *}$ & $-15.092^{\star * *}$ & $-12.646^{* * *}$ & $-13.825^{\star * *}$ \\
\hline & $(1.662)$ & $(1.446)$ & $(1.113)$ & $(1.186)$ \\
\hline $\mathrm{N}$ & 240 & 240 & 240 & 240 \\
\hline $\mathrm{r} 2$ & 0.766 & 0.806 & 0.865 & 0.864 \\
\hline r2_a & 0.764 & 0.802 & 0.861 & 0.859 \\
\hline
\end{tabular}

Standard errors in parentheses. ${ }^{*} \mathrm{p}<0.1,{ }^{* *} \mathrm{p}<0.05,{ }^{* * *} \mathrm{p}<0.01$.

the number of invention patents granted in province $i$ in year $t+3$. We analysed the innovation performance in different variants through columns (1) to (4): First, we introduced only the regression with the fundamental factors of innovation input, followed by the variables of innovation systems and institutions, step by step.

\subsection{Endogenous Growth}

According to Romer's endogenous growth theory, the volume of knowledge stock and the factor input determine innovation productivity. In column (1), we used the logarithm of GDP per capita and full-time equivalents of R \& D personnel as indicators of the basic input level. According to regression results, both of the factors have positive effects on innovation performance. If GDP per capita increases by $10 \%$, the number of patents granted rises by approximately $14.38 \%$. 
If a region hires $10 \%$ more $\mathrm{R} \& \mathrm{D}$ staff, the number of patents granted goes up by approximately $8.74 \%$.

\subsection{Innovation Milieu}

As explained above, the regional innovative capacity depends not only on innovation input, but also on the institutional milieu. Column (2) includes all variables of the innovation infrastructure. Both of the innovation infrastructure factors, OPENNESS (0.016) and ED_SHARE (0.090), have significantly positive effects. Although China's transition strategy since the late 1970s has been called the "reform and opening-up policy", "reform" and "opening-up" were in fact two separate parts, meaning that they were not simultaneously implemented. Opening-up was an engine for China's reform. Each further process of opening up brought the transition a step forward [37]. The opening-up policy "forced" China to participate in the global division of labor and international competition. The other factor, education expenditure by local government, remains at a significant level, suggesting that policy variation plays an important role in determining innovation output. The amount of patents granted rises by approximately $0.9 \%$ if the government spends $10 \%$ more on education.

Indicators of cluster circumstances were then added into the regressions. Furman, Porter and Stern [3] argue that the environment for innovation in industrial clusters is difficult to measure due to the subtlety of the concepts involved as well as the lack of systematic data. Because of the limit of data, we only used the development of tertiary sectors as indicator of industrial clusters. It is evident that TERTIARY contributes to innovation output. Provinces where the service sector is well developed are particularly innovative. One of the reasons for this could be that the tertiary sector contains a large number of industries that supply innovation activities with necessary services. Moreover, if we observe the financing channel, we find that if banks dominate the financing channel of $S$ $\& \mathrm{~T}$ activities, the innovation output decreases.

The last factor that we observed is the influence of marketization reform. Columns (3) and (4) introduce the two marketization indicators respectively: intermediary organizations (INTER) and protection for intellectual property (IP). It is remarkable that both of these have significantly positive effects. Every additional unit of INTER and IP increases the amount of patents granted by around $0.87 \%$ and $0.44 \%$, respectively. This proves that institutions influence innovation output in China and that a market-oriented system increases regional innovation performance.

In Table 4, we replaced the dependent variable, the logarithm of the number of patents granted (L_PATENT_GRA), with the logarithm of the number of patents granted per million people (L_PATENT_POP) and estimated columns (1) to (4) once again in order to test the results' robustness. The coefficients are similar to those in Table 3. From columns (1) to (4) the variables L_GDP_PC and L_PERSONAL are positive and significant. We interpret this to suggest that the 
Table 4. Estimation results (granted patents per million people as dependent variable).

\begin{tabular}{|c|c|c|c|c|}
\hline & (1) & (2) & (3) & (4) \\
\hline \multirow[t]{2}{*}{ L_GDP_PC } & $1.406^{\star \star \star}$ & $1.339^{* * *}$ & $1.105^{\star * *}$ & $1.241^{\star * *}$ \\
\hline & $(0.185)$ & $(0.178)$ & $(0.196)$ & $(0.188)$ \\
\hline \multirow[t]{2}{*}{ L_PERSONAL } & $0.836^{* * *}$ & $0.634^{* * *}$ & $0.333^{* *}$ & $0.370^{* * *}$ \\
\hline & $(0.164)$ & $(0.147)$ & $(0.126)$ & $(0.132)$ \\
\hline \multirow[t]{2}{*}{ OPENNESS } & & $0.014^{* * *}$ & $0.011^{\star * *}$ & $0.008^{*}$ \\
\hline & & $(0.003)$ & $(0.003)$ & $(0.004)$ \\
\hline \multirow[t]{2}{*}{ ED_SHARE } & & $0.085^{\star * *}$ & $0.057^{* *}$ & $0.055^{* *}$ \\
\hline & & $(0.025)$ & $(0.026)$ & $(0.024)$ \\
\hline \multirow[t]{2}{*}{ INTER } & & & $0.088^{\star * *}$ & \\
\hline & & & $(0.019)$ & \\
\hline \multirow[t]{2}{*}{ IP } & & & & $0.043^{* * *}$ \\
\hline & & & & $(0.014)$ \\
\hline \multirow[t]{2}{*}{ TERTIARY } & & & $0.072^{\star * *}$ & $0.072^{\star \star \star}$ \\
\hline & & & $(0.010)$ & $(0.011)$ \\
\hline \multirow[t]{2}{*}{ UNI_RD } & & & 0.004 & 0.002 \\
\hline & & & $(0.006)$ & $(0.006)$ \\
\hline \multirow[t]{2}{*}{ BANK } & & & -0.013 & $-0.014^{\star}$ \\
\hline & & & $(0.008)$ & $(0.007)$ \\
\hline \multirow[t]{2}{*}{ _cons } & $-19.034^{\star * *}$ & $-18.145^{\star * *}$ & $-15.702^{* * *}$ & $-16.932^{* * *}$ \\
\hline & $(1.628)$ & $(1.472)$ & $(1.244)$ & $(1.240)$ \\
\hline $\mathrm{N}$ & 240 & 240 & 240 & 240 \\
\hline $\mathrm{r} 2$ & 0.763 & 0.797 & 0.863 & 0.860 \\
\hline r2_a & 0.761 & 0.794 & 0.858 & 0.856 \\
\hline
\end{tabular}

Standard errors in parentheses. ${ }^{*} \mathrm{p}<0.1,{ }^{* *} \mathrm{p}<0.05,{ }^{* * *} \mathrm{p}<0.01$.

classic determinants of innovation are also important motors for innovation performance. The other results are also robust to the modification: OPENNESS, ED_SHARE, INTER, IP, TERTIARY and BANK.

\section{Conclusions}

In this paper, we estimate the effects of innovation systems on regional innovation performance in China. For this purpose, we established a dataset across 30 provincial-level regions between 1998 and 2008. The results indicate that the traditional innovation factors including innovation input and knowledge accumulation, and innovation system contribute to increasing the level of innovation. Institutional arrangements also affect innovation output.

The different factors of the innovation system have different effects: innovation infrastructure, including the level of openness of a region and government 
expenditure on education, is necessary for innovation. Another result is that the extent of bank credit does not influence innovation output. The frequent engagement of banks in R \& D financing cannot promote the level of innovation.

Finally, our results suggest that institutional factors play an important role in increasing the level of innovation. A market-oriented economic structure, especially healthy intermediary organizations and protection of intellectual property, helps a region to achieve a better outcome in innovation activities.

In political terms, the findings suggest that an ideas-driven growth model is appropriate for innovative activities in China. The provinces should not only concentrate on training sophisticated engineers and researchers but also attempt to participate in international competition and focus on the education and training of new generations. It is necessary to continue to promote China's economic reform and transformation to a market economy. For local governments, it is beneficial to build a framework of economic fairness for the intermediary market to provide infrastructure services to innovation performers.

\section{Acknowledgements}

I would like to thank Ulrich Blum, Shi Shiwei, Rainer Frietsch, Henning Kroll, Guo Bin, Thomas Schøtt and Philipp Boeing for helpful discussions. I thank Humboldt Forum in Beijing, China; China Innovation Circles and Academy-Learning, Innovation and Competence Systems (CICALICS) academy in Hangzhou, China; and Fraunhofer Institute for Systems and Innovation Research (ISI) for valuable comments.

\section{References}

[1] OECD (1997) National Innovation Systems. http://www.oecd.org/science/inno/2101733.pdf

[2] Patel, P. and Pavitt, K. (1994) National Innovation Systems: Why They Are Important, and How They Might Be Measured and Compared. Economics of Innovation and New Technology, 3, 77-95. https://doi.org/10.1080/10438599400000004

[3] Furman, J.L., Porter, M.E. and Stern, S. (2002) The Determinants of National Innovative Capacity. Research Policy, 31, 899-933. https://doi.org/10.1016/S0048-7333(01)00152-4

[4] Hu, M.-C. and Mathews, J.A. (2005) National Innovative Capacity in East Asia. Research Policy, 34, 1322-1349. https://doi.org/10.1016/j.respol.2005.04.009

[5] Hu, M.-C. and Mathews, J.A. (2008) China's National Innovative Capacity. Research Policy, 37, 1465-1479. https://doi.org/10.1016/j.respol.2008.07.003

[6] Rosenberg, N. and Nelson, R.R. (1994) American Universities and Technical Advance in Industry. Research Policy, 23, 323-348. https://doi.org/10.1016/0048-7333(94)90042-6

[7] Asheim, B.T, and Isaksen, A. (2002) Regional Innovation Systems: The Integration of Local 'Sticky' and Global 'Ubiquitous' Knowledge. The Journal of Technology Transfer, 27, 77-86. https://doi.org/10.1023/A:1013100704794

[8] Fan, G., Wang, X. and Zhu, H. (2011) NERI INDEX of Marketization of China's Provinces 2011 Report. Economic and Science Press, Beijing. (In Chinese) 
[9] Kou, K. (2015) Auswirkungen des chinesischen Innovationsmilieus auf das regionale Wachstumspotenzial. In: Blum, U., Ed., Cultural Heritage and Green Economy. Technology, Industrial Growth, Mobility, Beijing Humboldt Forum (Vol. 4), Martin-Luther-Univ, Halle (Saale), 41-61.

[10] Blum, U., Veltins, M., Bauer, H. and Huber, F. (2004) Marktmacht, Kartelle und die Berechnung des Mehrerlöses. Strategien und Trends im Handelsmanagement. Bauer, H. and Huber, F., Eds. Vahlen, München, 251-271.

[11] Romer, P. (1990) Endogenous Technological Change. Journal of Political Economy, 98, 71-102. https://doi.org/10.1086/261725

[12] Porter, M.E. (1990) The Competitive Advantage of Nations. Harvard Business Review, 68, 73-93.

[13] Nelson, R.R. (1993) National Innovation Systems: A Comparative Analysis. Oxford University Press, Oxford.

[14] UNESCAP (2009) What Is Good Governance? United Nations Economic and Social Commission for Asia and the Pacific, 1-3.

[15] Furman, J.L. and Hayes, R. (2004) Catching Up or Standing Still? National Innovative Productivity among "Follower" Countries, 1978-1999. Research Policy, 33, 1329-1354. https://doi.org/10.1016/j.respol.2004.09.006

[16] Liu, X. and White, S. (2001) Comparing Innovation Systems: A Framework and Application to China's Transitional Context. Research Policy, 30, 1091-1114. https://doi.org/10.1016/S0048-7333(00)00132-3

[17] Xu, C. (2011) The Fundamental Institutions of China's Reforms and Development. Journal of Economic Literature, 49, 1076-1151. https://doi.org/10.1257/jel.49.4.1076

[18] Li, X. (2007) An Empirical Analysis of the Change of Chinese Regional Innovation Capability: Based on the View of Innovation System. Management World, 12, 18-30. (In Chinese)

[19] Cheung, S.N.S. (2009) The 30th Anniversary of China's Economic Reform. CITIC Press, Beijing.

[20] Park, S.H., Li, S. and David, K.T. (2006) Market Liberalization and Firm Performance during China's Economic Transition. Journal of International Business Studies, 37, 127-147. https://doi.org/10.1057/palgrave.jibs.8400178

[21] Griliches, Z. (1984) R \& D, Patents and Productivity. University of Chicago Press, Chicago, IL.

[22] Griliches, Z. (1990) Patent Statistics as Economic Indicators: A Survey. Working Paper No. 3301. https://doi.org/10.3386/w3301

[23] Mansfield, E. (1986) Patents and Innovation: An Empirical Study. Management Science, 32, 173-181. https://doi.org/10.1287/mnsc.32.2.173

[24] Pavitt, K. (1988) Uses and Abuses of Patent Statistics. In: Handbook of Quantitative Studies of Science and Technology, Elsevier, Amsterdam, 509-536. https://doi.org/10.1016/B978-0-444-70537-2.50021-0

[25] Schmookler, J. (1966) Invention and Economic Growth. Harvard University Press, Cambridge, MA. https://doi.org/10.4159/harvard.9780674432833

[26] Acs, Z.J. and Audretsch, D.B. (1989) Patents as a Measure of Innovative Activity. Kyklos, 42, 171-180. https://doi.org/10.1111/j.1467-6435.1989.tb00186.x

[27] Acs, Z.J., Anselin, L. and Varga, A. (2002) Patents and Innovation Counts as Measures of Regional Production of New Knowledge. Research Policy, 31, 1069-1085. https://doi.org/10.1016/S0048-7333(01)00184-6 
[28] Li, X. (2012) Behind the Recent Surge of Chinese Patenting: An Institutional View. Research Policy, 41, 236-249. https://doi.org/10.1016/j.respol.2011.07.003

[29] Li, X. (2007) An Empirical Analysis of the Effect of Institutional Factors on Regional Innovation Performance. The Journal of Quantitative \& Technical Economics, 24, 13-24. (In Chinese)

[30] Fan, G., Wang, X. and Zhu, H. (2006) NERI Index of Marketization of China's Provinces: 2006 Report. Economic Science Press, Beijing.

[31] Wang, Q., Wong, T.-J. and Xia, L. (2008) State Ownership, the Institutional Environment, and Auditor Choice: Evidence from China. Journal of Accounting and Economics, 46, 112-134. https://doi.org/10.1016/j.jacceco.2008.04.001

[32] Chen, G., Firth, M., Gao, D.N. and Rui, O.M. (2006) Ownership Structure, Corporate Governance, and Fraud: Evidence from China. Journal of Corporate Finance, 12, 424-448. https://doi.org/10.1016/j.jcorpfin.2005.09.002

[33] Firth, M., Lin, C., Liu, P. and Wong, S.M.L. (2009) Inside the Black Box: Bank Credit Allocation in China's Private Sector. Journal of Banking \& Finance, 33, 1144-1155. https://doi.org/10.1016/j.jbankfin.2008.12.008

[34] Li, K., Yue, H. and Zhao, L. (2009) Ownership, Institutions, and Capital Structure: Evidence from China. Journal of Comparative Economics, 37, 471-490. https://doi.org/10.1016/j.jce.2009.07.001

[35] Chen, G., Firth, M. and Xu, L. (2009) Does the Type of Ownership Control Matter? Evidence from China's Listed Companies. Journal of Banking \& Finance, 33, 171-181. https://doi.org/10.1016/j.jbankfin.2007.12.023

[36] Lundvall, B.-Å., Johnson, B., Andersen, E.S. and Dalum, B. (2002) National Systems of Production, Innovation and Competence Building. Research Policy, 31, 213-231. https://doi.org/10.1016/S0048-7333(01)00137-8

[37] Shi, S. (2009) Auswirkungen des Beitritts Chinas zur WTO auf die Wettbewerbspolitik in China: Eine institutionenöknomische Betrachtung. Discussion Paper, Europa-Kolleg Hamburg, Institute for European Integration, No. 2/09. 